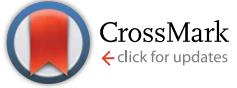

Cite this: RSC Adv., 2015, 5, 41401
Received 30th March 2015 Accepted 21st April 2015

DOI: $10.1039 / \mathrm{c} 5 \mathrm{ra05604g}$

www.rsc.org/advances

\section{The importance of $\mathrm{Au} \cdots \pi(\mathrm{aryl})$ interactions in the formation of spherical aggregates in binuclear phosphane gold(I) complexes of a bipodal thiocarbamate dianion: a combined crystallographic and computational study, and anti-microbial activity $\dagger$}

\begin{abstract}
Chien Ing Yeo, ${ }^{a}$ Chai-Hoon Khoo, ${ }^{\mathrm{b}}$ Wern-Cui Chu, ${ }^{\mathrm{b}}$ Bao-Jing Chen, ${ }^{\mathrm{b}}$ Pek-Lim Chu, ${ }^{\mathrm{b}}$ Jiun-Horng Sim, ${ }^{b}$ Yoke-Kqueen Cheah, ${ }^{* b}$ Jimmy Ahmad, ${ }^{a}$ Siti Nadiah Abdul Halim, ${ }^{a}$ Hoi-Ling Seng, ${ }^{c}$ Soon Ng, ${ }^{a}$ A. Otero-de-la-Roza ${ }^{* d}$ and Edward R. T. Tiekink ${ }^{* a}$

Binuclear phosphanegold( $(1)$ complexes of a bipodal thiocarbamate dianion, $\left(\mathrm{R}_{3} \mathrm{PAu}\right)_{2} \mathrm{~L}, \mathrm{R}=\mathrm{Et}(1), \mathrm{Ph}(2)$ and Cy (3), where $\mathrm{LH}_{2}$ is $\left\{1,4-[\mathrm{MeOC}(=\mathrm{S}) \mathrm{N}(\mathrm{H})]_{2} \mathrm{C}_{6} \mathrm{H}_{4}\right\}$, have been synthesised, and characterised spectroscopically (NMR and IR) and by X-ray crystallography. The gold atoms are linearly coordinated within a $P$-,S-donor set, and are oriented toward the central ring to form intramolecular Au $\cdots \pi($ aryl) interactions, rather than the intramolecular $A u \cdots O$ interactions normally observed in mononuclear analogues. This phenomenon has been investigated by theory (LC- $\omega$ PBE-XDM) for 1 which revealed that the geometry optimised species with two Au $\cdots \pi\left(\right.$ aryl) interactions is more stable by at least $12 \mathrm{kcal} \mathrm{mol}^{-1}$

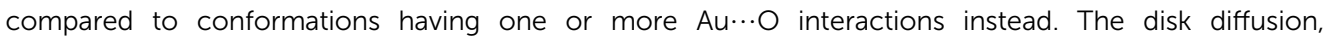
minimum inhibitory concentration (MIC) and minimum bactericidal concentration (MBC) methods were used to observe the inhibitory effect of complexes 1-3. The disk diffusion results demonstrated that 1 exhibited a broad spectrum of anti-bacterial activity toward 24 strains of Gram-positive and Gramnegative bacteria. By contrast, the anti-bacterial activity of 2 and 3 was limited to Gram-positive bacteria. Further evaluation showed that 1 exhibited marked bactericidal activity against B. cereus, B. subtilis, E. faecalis, L. monocytogenes, S. aureus, S. saprophyticus and methicillin resistant S. aureus cf. standard antibiotics tetracycline and chloramphenicol.
\end{abstract}

\section{Introduction}

The structural diversity and the fascinating architectures they sustain have ensured that aurophilic $(\mathrm{Au} \cdots \mathrm{Au})$ interactions have garnered the attention of chemists for decades. ${ }^{1}$ The aggregation of gold compounds in this fashion arises from relativistic effects which are at a maximum for gold compared to other

${ }^{a}$ Department of Chemistry, University of Malaya, 50603 Kuala Lumpur, Malaysia. E-mail: Edward.Tiekink@gmail.com

${ }^{b}$ Department of Biomedical Science, Faculty of Medicine and Health Sciences, University Putra Malaysia, 43400 Serdang, Selangor Darul Ehsan, Malaysia. E-mail: ykcheah@medic.upm.edu.my

'Department of Biological Sciences, Faculty of Science and Technology, Sunway University, 47500 Bandar Sunway, Selangor Darul Ehsan, Malaysia

${ }^{d}$ National Institute for Nanotechnology, National Research Council of Canada, 11421 Saskatchewan Drive, Edmonton, Alberta, Canada T6G 2M9. E-mail: alberto. oterodelaroza@nrc-cnrc.gc.ca

$\dagger$ Electronic supplementary information (ESI) available. CCDC 1041500-1041502. For ESI and crystallographic data in CIF or other electronic format see DOI: $10.1039 / \mathrm{c} 5 \mathrm{ra} 05604 \mathrm{~g}$ heavy elements. ${ }^{2}$ Over and above aesthetics, interest in gold compounds/aurophilic interactions stems from their luminescence properties, in both the solid-state and in solution. ${ }^{3}$ By contrast to aurophilic interactions, the recognition of supramolecular association based on $\mathrm{Au} \cdots \pi($ aryl) interactions is still in its infancy, ${ }^{4 a}$ despite them being often crucial in the reaction mechanisms related to the burgeoning field of gold-based catalysis. ${ }^{5}$ It is only in recent years that bibliographic surveys have shown that $\mathrm{Au}^{\cdots} \pi($ aryl) interactions provide readily identifiable points of contact between molecules in their crystal structures, operating in isolation of other supramolecular synthons. ${ }^{4}$

The themes of aurophilic and $\mathrm{Au} \cdots \pi($ aryl) interactions as well as luminescence feature prominently in the chemistry of phosphanegold(I) thiocarbamates, where the thiolate anion is derived from thiocarbamide molecules of the general formula $\mathrm{RN}(\mathrm{H}) \mathrm{C}(=\mathrm{S}) \mathrm{OR}^{\prime}, \mathrm{R}, \mathrm{R}^{\prime}=$ alkyl and/or aryl. ${ }^{6}$ In the overwhelming majority of crystal structures of phosphanegold(I) thiocarbamates, the thiolate ligand is oriented so that the oxygen 
atom is located in close proximity to the gold atom. However, by careful choice of $\mathrm{R}$ and $\mathrm{R}^{\prime}$ substituents of the thiolate anion and by using isomeric tolylphosphane ligands, it proved possible to orient the thiolate so that the aryl ring was proximate to the gold atom instead. ${ }^{6 c}$ Crystal engineering considerations notwithstanding, phosphanegold(I) thiocarbamates also exhibit promising biological activity.

Gold(I) compounds are used clinically in the treatment of severe forms of rheumatoid arthritis, being a member of the disease modifying anti-rheumatic drugs (DMARDS) class of antiarthritic agents. ${ }^{7 a-c}$ Spurred by the observation that patients undergoing chrysotherapy, appeared to suffer reduced rates of malignant disease, ${ }^{7 d}$ both gold(I) and gold(III) compounds are under intense investigation as potential anti-tumour drugs. ${ }^{8}$ In the context of the present study, phosphanegold(I) thiocarbamates of the general formula $\mathrm{Ph}_{3} \mathrm{PAu}[\mathrm{SC}(\mathrm{OR})=\mathrm{NPh}], \mathrm{R}=\mathrm{Me}$, Et and iPr, exhibit significant cytotoxicity toward HT-29 colon cancer cells, have been shown to function through both intrinsic and extrinsic apoptotic pathways, and to be topoisomerase I inhibitors. ${ }^{9}$ Gold compounds are also under active evaluation as anti-microbial agents. ${ }^{10}$ Recently, another series of phosphanegold(I) thiocarbamates, namely $\mathrm{Ph}_{3} \mathrm{PAu}[\mathrm{SC}(\mathrm{OR})=\mathrm{N}(p$-tol $)], \mathrm{R}=\mathrm{Me}$, Et and iPr, have proven to be very effective against a panel of Grampositive bacteria. ${ }^{11}$

It was primarily the biological context that led to the synthesis of the title binuclear compounds, $\left(\mathrm{R}_{3} \mathrm{PAu}\right)_{2} \mathrm{~L}, \mathrm{R}=\mathrm{Et}$ (1), Ph (2) and Cy (3), where $\mathrm{LH}_{2}$ is the bipodal molecule $\{1,4$ $\left.[\mathrm{MeOC}(=\mathrm{S}) \mathrm{N}(\mathrm{H})]_{2} \mathrm{C}_{6} \mathrm{H}_{4}\right\}$. Herein, their characterization, including by X-ray crystallography and Density Functional Theory (DFT) calculations is described along with an evaluation of their potential anti-microbial activity.

\section{Experimental section}

\section{Materials, methods and Instruments}

All chemicals and solvents were used as purchased without purification. All reactions were carried out under ambient conditions. Elemental analyses were performed on a Perkin Elmer PE $2400 \mathrm{CHN}$ Elemental Analyser. Melting points were determined on a Krüss KSP1N melting point meter. ${ }^{1} \mathrm{H}$ and ${ }^{13} \mathrm{C}$ $\left\{{ }^{1} \mathrm{H}\right\}$ NMR spectra were recorded in both DMSO- $d_{6}$ and $\mathrm{CDCl}_{3}$ solutions for $\mathrm{LH}_{2}$, and $\mathrm{CDCl}_{3}$ solutions for 1-3 on a Bruker Avance $400 \mathrm{MHz}$ NMR spectrometer with chemical shifts relative to tetramethylsilane. ${ }^{31} \mathrm{P}\left\{{ }^{1} \mathrm{H}\right\}$ NMR spectra were recorded in $\mathrm{CDCl}_{3}$ solution on the same instrument but with the chemical shifts recorded relative to $85 \%$ aqueous $\mathrm{H}_{3} \mathrm{PO}_{4}$ as the external reference; abbreviations for NMR assignments: s, singlet; $d$, doublet; m, multiplet; dq, doublet of quartets; dt, doublet of triplets. For the relaxation experiments on $\mathbf{1}$, a solution of the compound $(20 \mathrm{mg})$ was prepared in $\mathrm{CDCl}_{3}(4.5 \mathrm{~cm})$ in a $5 \mathrm{~mm}$ NMR tube (Wilmad). The solution was degassed through five freeze-pump-thaw cycles and sealed under vacuum. The NMR measurements were carried out on a JEOL ECX500 NMR spectrometer. The ${ }^{13} \mathrm{C}$ spin-lattice relaxation time $\left(T_{1}\right)$ was obtained by using the two-pulse inversion-recovery (IR) method. ${ }^{\mathbf{1 2}}$ Initially, an approximate $T_{1}$ value was obtained before a more precise measurement was made using 10 IR intervals in a range up to $1.5 T_{1}$. Subsequently, a final measurement was made to confirm the value $T_{1}=0.69 \mathrm{~s}$ at $20{ }^{\circ} \mathrm{C}$. Then, the NOE measurements were made in two consecutive experiments: one with complete proton decoupling with a relaxation delay of $6.0 \mathrm{~s}$ and an acquisition time of $1.04 \mathrm{~s}$, and the other experiment with gated-decoupling in which the NOE was suppressed but with the remaining conditions the same as in the first experiment. The pulse angle was $90^{\circ}$. Good signal intensity was obtained with 1024 scans. The total integrated intensity of the signal was obtained with the spectrometer's data processing software. The ratio of the signal intensities in the two experiments gives the NOE value, usually given as NOE $=1+\eta$, where $\eta$ is the NOE enhancement factor. IR spectra were measured on a Perkin Elmer Spectrum 400 FT Mid-IR/Far-IR spectrophotometer from 4000 to $400 \mathrm{~cm}^{-1}$; abbreviations: vs, very strong; s, strong; m, medium; br, broad. Thermogravimetric analyses were performed on a Perkin Elmer TGA 4000 Thermogravimetric Analyzer in the range of $35-850{ }^{\circ} \mathrm{C}$ at the rate of $10^{\circ} \mathrm{C} \mathrm{min}^{-1}$. Powder X-ray diffraction (PXRD) data were recorded with a PANalytical Empyrean XRD system with $\mathrm{Cu}-\mathrm{K} \alpha 1$ radiation $(\lambda=1.54056 \AA)$ in the $2 \theta$ range 5 to $50^{\circ}$. The comparison between experimental and calculated (from CIF's) PXRD patterns were performed with X'Pert HighScore Plus. ${ }^{13}$

Synthesis of $\mathbf{L H}_{2} \cdot \mathbf{L H}_{2}$ was prepared in similar manner as described in the literature for mono-functional analogues ${ }^{\mathbf{1 4}}$ whereby $p$-phenylene diisothiocyanate $(2.50 \mathrm{mmol}, 0.48 \mathrm{~g}$; Sigma-Aldrich) was reacted in $\mathrm{MeOH}(100 \mathrm{ml})$ in the presence of two mole equivalents of $\mathrm{NaOH}$, yielding a pale-yellow powder. Yield: $0.596 \mathrm{~g}$ (93\%). $\mathrm{mp} 209.0-210.0{ }^{\circ} \mathrm{C}$. Anal. calc. for $\mathrm{C}_{10} \mathrm{H}_{12} \mathrm{~N}_{2} \mathrm{O}_{2} \mathrm{~S}_{2}$ : C, 46.85; H, 4.72; N, 10.93. Found: C, 46.71; $\mathrm{H}$, 4.64; N, 10.94\%. IR (, $\left.\mathrm{cm}^{-1}\right): 3219(b r) v(\mathrm{~N}-\mathrm{H}), 1454(\mathrm{~s}) v(\mathrm{C}-\mathrm{N})$, $1140(\mathrm{~s}) v(\mathrm{C}-\mathrm{O}), 1046(\mathrm{~s}) v(\mathrm{C}=\mathrm{S}) .{ }^{1} \mathrm{H}$ NMR (DMSO- $\left.d_{6}\right): \delta 11.10[\mathrm{~s}$, br, 2H, NH], 7.59 [s, br, 2H, aryl-H], 7.30 [s, br, 2H, aryl-H], 3.99 $\left[\mathrm{s}, 6 \mathrm{H}, \mathrm{OCH}_{3}\right] \mathrm{ppm} .{ }^{1} \mathrm{H} \mathrm{NMR}(\mathrm{CDCl} 3): \delta 8.32[\mathrm{~s}, \mathrm{br}, 2 \mathrm{H}, \mathrm{NH}], 7.56$ $\left[\mathrm{s}, \mathrm{br}, 2 \mathrm{H}\right.$, aryl-H], $7.22\left[\mathrm{~s}, \mathrm{br}, 2 \mathrm{H}\right.$, aryl-H], $4.12\left[\mathrm{~s}, 6 \mathrm{H}, \mathrm{OCH}_{3}\right]$ ppm. ${ }^{13} \mathrm{C}\left\{{ }^{1} \mathrm{H}\right\}$ NMR (DMSO- $d_{6}$ ): $\delta$ 189.1, $188.4\left[C_{\mathrm{q}}\right], 135.8,134.8$ $\left[C_{\text {ipso }}\right], 123.7$ and $122.6\left[C_{\text {ortho }}\right], 58.3,56.8\left[\mathrm{OCH}_{3}\right] \mathrm{ppm}$.

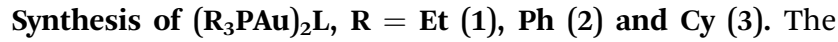
methods employed for the preparation and recrystallization of 1-3 were similar, so the preparation of the $\mathrm{Et}_{3} \mathrm{P}$ derivative (1) is described in detail as a representative example. The $\mathrm{R}_{3} \mathrm{PAuCl}, \mathrm{R}$ $=\mathrm{Et}, \mathrm{Ph}$ and $\mathrm{Cy}$, precursors employed in the synthesis were prepared following standard procedures by reducing $\mathrm{KAuCl}_{4}$ (Sigma-Aldrich) using one mole excess sodium sulfite (Merck), and then further reacted with one mole equivalent of either $\mathrm{Et}_{3} \mathrm{P}$ (Merck), $\mathrm{Ph}_{3} \mathrm{P}$ (Merck) or $\mathrm{Cy}_{3} \mathrm{P}$ (Sigma-Aldrich), to yield the respective precursor.

$\left(E t_{3} P A u\right)_{2} L(1) . \mathrm{NaOH}(0.50 \mathrm{mmol})$ in water $(5 \mathrm{ml})$ was added to a suspension of $\mathrm{Et}_{3} \mathrm{PAuCl}(0.50 \mathrm{mmol})$ in acetonitrile $(20 \mathrm{ml})$ followed by addition of $\mathrm{LH}_{2}(0.25 \mathrm{mmol})$ in acetonitrile $(20 \mathrm{ml})$. The resulting mixture was stirred for $3 \mathrm{~h}$ at $50{ }^{\circ} \mathrm{C}$. Extraction followed with dichloromethane $(100 \mathrm{ml})$ and an equivalent volume of acetonitrile added. The solution was left for slow evaporation at room temperature, giving colourless crystals after 2 weeks. Yield: $0.206 \mathrm{~g}$ (93\%). mp 174.0-176.0 ${ }^{\circ} \mathrm{C}$. Anal. calc. for $\mathrm{C}_{22} \mathrm{H}_{40} \mathrm{Au}_{2} \mathrm{~N}_{2} \mathrm{O}_{2} \mathrm{P}_{2} \mathrm{~S}_{2}$ : C, 29.87; H, 4.56; N, 3.17. Found: $\mathrm{C}, 29.92 ; \mathrm{H}, 4.53 ; \mathrm{N}, 3.04 \%$. IR $\left(\mathrm{cm}^{-1}\right): 1421(\mathrm{~m}) v(\mathrm{C}=\mathrm{N})$, 
1123 (vs) v(C-O), 1094 (s) v(C-S). ${ }^{1} \mathrm{H}$ NMR $\left(\mathrm{CDCl}_{3}\right): \delta 6.72[\mathrm{~s}, 4 \mathrm{H}$, aryl-H], $3.81\left[\mathrm{~s}, 6 \mathrm{H}, \mathrm{OCH}_{3}\right], 1.70\left[\mathrm{dq}, 12 \mathrm{H}, \mathrm{CH}_{2} \mathrm{P},{ }^{3} J_{\mathrm{HH}}=7.75,{ }^{2} J_{\mathrm{PH}}\right.$ $=9.82 \mathrm{~Hz}], 1.06\left[\mathrm{dt}, 18 \mathrm{H}, \mathrm{CH}_{3} \mathrm{CH}_{2} \mathrm{P},{ }^{3} J_{\mathrm{HH}}=7.62,{ }^{3} J_{\mathrm{PH}}=18.32 \mathrm{~Hz}\right]$ ppm. ${ }^{13} \mathrm{C}\left\{{ }^{1} \mathrm{H}\right\} \operatorname{NMR}\left(\mathrm{CDCl}_{3}\right): \delta 165.3\left[C_{\mathrm{q}}\right], 145.7$ [aryl, $C_{\text {ipso }}$ ], 122.8 [aryl, $C_{\text {ortho }}$ ], $55.2\left[\mathrm{OCH}_{3}\right], 17.6\left[\mathrm{~d}, \mathrm{CH}_{2} \mathrm{P}^{1} J_{\mathrm{CP}}=33.3 \mathrm{~Hz}\right], 8.8[\mathrm{~s}$, $\left.\mathrm{CH}_{3} \mathrm{CH}_{2} \mathrm{P}\right]$ ppm. ${ }^{31} \mathrm{P}\left\{{ }^{1} \mathrm{H}\right\} \mathrm{NMR}\left(\mathrm{CDCl}_{3}\right): \delta 35.6 \mathrm{ppm}$.

$\left(P h_{3} P A u\right)_{2} L$ (2). A similar synthetic procedure as employed for 1 was used for the synthesis of 2 except that the gold precursor was replaced by $\mathrm{Ph}_{3} \mathrm{PAuCl}$. Colourless crystals. Yield: $0.255 \mathrm{~g}$ (87\%). mp 181.5-183.0 ${ }^{\circ}$ C. Anal. calc. for $\mathrm{C}_{46} \mathrm{H}_{40} \mathrm{Au}_{2} \mathrm{~N}_{2} \mathrm{O}_{2} \mathrm{P}_{2} \mathrm{~S}_{2}$ : C, 47.11; H, 3.44; N, 2.39. Found: C, 47.25; H, 3.31; N, 2.41\%. IR $\left(\mathrm{cm}^{-1}\right): 1434(\mathrm{~s}) v(\mathrm{C}=\mathrm{N}), 1143$ (s) $v(\mathrm{C}-\mathrm{O}), 1101$ (s) $v(\mathrm{C}-\mathrm{S}) \cdot{ }^{1} \mathrm{H}$ NMR $\left(\mathrm{CDCl}_{3}\right): \delta 7.49-7.41\left[\mathrm{~m}, 30 \mathrm{H}, \mathrm{Ph}_{3} \mathrm{P}\right], 6.41[\mathrm{~s}, 4 \mathrm{H}$, aryl-H], $3.73\left[\mathrm{~s}, 6 \mathrm{H}, \mathrm{OCH}_{3}\right] \mathrm{ppm} .{ }^{13} \mathrm{C}\left\{{ }^{1} \mathrm{H}\right\}$ NMR $\left(\mathrm{CDCl}_{3}\right): \delta 163.2\left[C_{\mathrm{q}}\right]$, 145.7 [aryl, $C_{i p s o}$ ], $134.4\left[\mathrm{~d}, o-\mathrm{Ph}_{3} \mathrm{P},{ }^{2} J_{\mathrm{CP}}=13.9 \mathrm{~Hz}\right], 131.4[\mathrm{~d}$, $\left.p-\mathrm{Ph}_{3} \mathrm{P},{ }^{4} J_{\mathrm{CP}}=2.2 \mathrm{~Hz}\right], 129.6\left[\mathrm{~d}, \mathrm{i}-\mathrm{Ph}_{3} \mathrm{P}, J_{\mathrm{CP}}=57.0 \mathrm{~Hz}\right], 128.9[\mathrm{~d}$, $m-\mathrm{Ph}_{3} \mathrm{P},{ }^{3} J_{\mathrm{CP}}=11.5 \mathrm{~Hz}$ ], 122.4 [aryl, $\left.C_{\text {ortho }}\right], 55.0\left[\mathrm{OCH}_{3}\right] \mathrm{ppm} .{ }^{31} \mathrm{P}$ $\left\{{ }^{1} \mathrm{H}\right\} \mathrm{NMR}\left(\mathrm{CDCl}_{3}\right): \delta 38.1 \mathrm{ppm}$.

$\left(C y_{3} P A u\right)_{2} L(3)$. The synthesis was as for 1 but using $\mathrm{Cy}_{3} \mathrm{PAuCl}$. Colourless crystals. Yield: $0.275 \mathrm{~g}$ (91\%). mp 180.0-181.0 ${ }^{\circ} \mathrm{C}$. Anal. calc. for $\mathrm{C}_{46} \mathrm{H}_{76} \mathrm{Au}_{2} \mathrm{~N}_{2} \mathrm{O}_{2} \mathrm{P}_{2} \mathrm{~S}_{2}$ : C, 45.69; H, 6.34; N, 2.32. Found: C, 45.57; H, 6.40; N, 2.24\%. IR $\left(\mathrm{cm}^{-1}\right): 1444(\mathrm{~s}) v(\mathrm{C}=\mathrm{N})$, $1130(\mathrm{~s}) v(\mathrm{C}-\mathrm{O}), 1093(\mathrm{~m}) v(\mathrm{C}-\mathrm{S}) .{ }^{1} \mathrm{H} \mathrm{NMR}\left(\mathrm{CDCl}_{3}\right): \delta 6.84[\mathrm{~s}, 4 \mathrm{H}$, aryl-H], $3.82\left[\mathrm{~s}, 6 \mathrm{H}, \mathrm{OCH}_{3}\right], 1.98-1.20\left[\mathrm{~m}, 66 \mathrm{H}, \mathrm{Cy}_{3} \mathrm{P}\right] \mathrm{ppm} .{ }^{13} \mathrm{C}$ $\left\{{ }^{1} \mathrm{H}\right\}$ NMR $\left(\mathrm{CDCl}_{3}\right): \delta 163.9\left[C_{\mathrm{q}}\right], 145.4$ [aryl, $C_{\text {ipso }}$ ], 122.4 [aryl, $\left.C_{\text {ortho }}\right], 54.8\left[\mathrm{OCH}_{3}\right], 33.3\left[\mathrm{~d}, 1-\mathrm{Cy}_{3} \mathrm{P}, J_{\mathrm{CP}}=27.8 \mathrm{~Hz}\right], 30.7[\mathrm{~s}$, $\left.3-\mathrm{Cy}_{3} \mathrm{P}\right], 27.0\left[\mathrm{~d}, 2-\mathrm{Cy}_{3} \mathrm{P},{ }^{3} J_{\mathrm{CP}}=11.9 \mathrm{~Hz}\right], 25.9\left[\mathrm{~s}, 4-\mathrm{Cy}_{3} \mathrm{P}\right] \mathrm{ppm} .{ }^{31} \mathrm{P}$ $\left\{{ }^{1} \mathrm{H}\right\} \mathrm{NMR}\left(\mathrm{CDCl}_{3}\right): \delta 56.5 \mathrm{ppm}$.

\section{X-ray data collection and structure determination}

Intensity data were measured at $100 \mathrm{~K}$ on an Agilent Technologies SuperNova Dual CCD with an Atlas detector fitted with Mo $\mathrm{K} \alpha$ radiation $(\lambda=0.71073 \AA)$. Data processing and absorption correction were accomplished with CrysAlis PRO. ${ }^{15 a}$ With the use of SHELX programs ${ }^{15 b}$ integrated into WinGX, ${ }^{15 c}$ the structures were solved by direct methods and refined on $F^{2}$ by fullmatrix least-squares with anisotropic displacement parameters for all non-hydrogen atoms. The C-bound $\mathrm{H}$ atoms were placed on stereochemical grounds and refined in the riding model approximation with $U_{\text {iso }}=1.2-1.5 U_{\text {eq }}$ (carrier atom). A weighting scheme of the form $w=1 /\left[\sigma^{2}\left(F_{\mathrm{o}}^{2}\right)+(a P)^{2}+b P\right]$ where $P=\left(F_{\mathrm{o}}{ }^{2}+2 F_{\mathrm{c}}{ }^{2}\right) / 3$ was introduced in each case. For 1 , the residual electron density peaks were located 0.95 and 0.96 from the $\mathrm{Au}$ atom, and for 2 , the peaks were 0.90 and 0.86 from the Au atom. Details of cell data, X-ray data collection and structure refinement are given in Table 1. The programs ORTEP-3 for Windows, ${ }^{15 c}$ PLATON, ${ }^{15 d}$ DIAMOND ${ }^{15 e}$ and QMol $^{15 f}$ were also used in the analysis.

\section{Powder X-ray diffraction}

Powder X-ray patterns (PXRD) measured on the bulk material for each of 1-3 were compared with the simulated patterns calculated based on the CIF's obtained for the experimental crystal structures. ${ }^{13}$ There is a high agreement between the patterns, ESI Fig. S1, $\dagger$ suggesting the single crystal results are representative of the bulk materials.

\section{Computational study}

The calculations were run using Gaussian09 (ref. 16) and the $\mathrm{LC}-\omega \mathrm{PBE}^{\mathbf{1 7}}$ functional combined with the exchange-hole dipole moment (XDM) model dispersion correction, ${ }^{\mathbf{1 8 - 2 0}}$ implemented in the postg program. ${ }^{21}$ In a previous contribution, it was shown that LC- $\omega$ PBE-XDM gives excellent performance in the treatment of aurophilicity, ${ }^{22}$ so it is a reasonable choice to study interactions involving gold. Three conformations were examined for 1: (i) the same conformation as in the crystal structure, with two Au $\cdots \pi($ aryl) contacts, (ii) a mixed conformation with one $\mathrm{Au} \cdots \pi(\operatorname{aryl})$ and one $\mathrm{Au} \cdots \mathrm{O}$ contact, i.e. where one $\mathrm{Au} \cdots \pi(\operatorname{aryl})$ interaction of the experimental structure was replaced by a contact between gold and a thiocarbamate-O atom, and (iii) the fully extended, rod-like conformations with two $\mathrm{Au} \cdots \mathrm{O}$ interactions. The geometry of each conformer was relaxed using the 6$31+\mathrm{G}^{*}$ basis set for all s- and p-block elements and aug-cc-pVDZPP scalar relativistic pseudo-potential and basis set combination for $\mathrm{Au} .^{23}$ Despite the modest size of this basis set, it has been shown in previous work that just one set of diffuse and polarization functions is sufficient to model non-covalent interactions with an accuracy relatively close to the basis-set limit. ${ }^{24}$

\section{Anti-microbial assay}

Bacterial strains. The standard reference strains of bacteria used in the present study were Aeromonas hydrophila (A. hydrophila) ATCC 35654, Acinetobacter baumannii (A. baumannii) ATCC 19606, Bacillus cereus (B. cereus) ATCC 10876, Bacillus subtilis (B. subtilis) ATCC 6633, Citrobacter freundii (C. reundii) ATCC 8090, Enterobacter cloacae (E. cloacae) ATCC 35030, Enterobacter aerogenes (E. aerogenes) ATCC 13048, Enterococcus faecalis (E. faecalis) ATCC 29212, Enterococcus faecium (E. faecium) ATCC 19434, Escherichia coli (E. coli) ATCC 25922, Klebsiella pneumoniae ( $K$. pneumoniae) ATCC 700603, Listeria monocytogenes (L. monocytogenes) ATCC 19117, Proteus mirabilis (P. mirabilis) ATCC 25933, Proteus vulgaris (P. vulgaris) ATCC 13315, Pseudomonas aeruginosa (P. aeruginosa) ATCC 27853, Salmonella paratyphi A (S. paratyphi A) ATCC 9150, Salmonella typhimurium (S. typhimurium) ATCC 14028, Shigella flexneri (S. flexneri) ATCC 12022, Shigella sonnei (S. sonnei) ATCC 9290, Staphylococcus aureus (S. aureus) ATCC 25923, methicillin resistant Staphylococcus aureus (MRSA) ATCC 43300, Staphylococcus saprophyticus (S. saprophyticus) ATCC 15305, Stenotrophomonas maltophilia (S. maltophilia) ATCC 13637 and Vibrio parahaemolyticus (V. parahaemolyticus) ATCC 17802. All bacterial strains were purchased from the American Type Culture Collection (ATCC, Manassas, VA, USA).

Anti-bacterial activity. The anti-bacterial activity of 1-3 was evaluated using the Kirby-Bauer disc diffusion method in accordance with the National Committee for Clinical Laboratory Standards (NCCLS) guidelines. The bacterial cultures were adjusted to 0.5 McFarland standard turbidity (which corre-

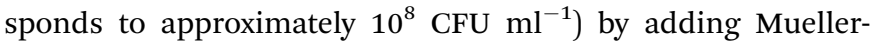
Hinton broth (Difco, USA). This suspension was then swabbed onto the surface of Mueller-Hinton agar (Difco, USA) plates. The tested compounds were dissolved in DMSO to a test concentration of $2 \mathrm{mg} \mathrm{ml}^{-1}$. Sterile $6 \mathrm{~mm}$ filter paper discs were 
Table 1 Crystal data, data collection and refinement parameters for compounds 1-3

\begin{tabular}{|c|c|c|c|}
\hline & 1 & 2 & 3 \\
\hline Formula & $\mathrm{C}_{22} \mathrm{H}_{40} \mathrm{Au}_{2} \mathrm{~N}_{2} \mathrm{O}_{2} \mathrm{P}_{2} \mathrm{~S}_{2}$ & $\mathrm{C}_{46} \mathrm{H}_{40} \mathrm{Au}_{2} \mathrm{~N}_{2} \mathrm{O}_{2} \mathrm{P}_{2} \mathrm{~S}_{2}$ & $\mathrm{C}_{46} \mathrm{H}_{76} \mathrm{Au}_{2} \mathrm{~N}_{2} \mathrm{O}_{2} \mathrm{P}_{2} \mathrm{~S}_{2}$ \\
\hline Formula weight & 884.56 & 1172.79 & 1209.08 \\
\hline Crystal size (mm) & $0.10 \times 0.20 \times 0.25$ & $0.20 \times 0.20 \times 0.30$ & $0.20 \times 0.30 \times 0.30$ \\
\hline Crystal system & Monoclinic & Triclinic & Monoclinic \\
\hline Space group & $P 2_{1} / c$ & $P \overline{1}$ & $P 2_{1} / n$ \\
\hline$a / \AA$ & $6.8843(6)$ & $8.9980(4)$ & $9.7522(3)$ \\
\hline$b \AA$ & $11.6056(7)$ & $9.0501(4)$ & $12.2227(3)$ \\
\hline$c / \AA$ & $17.7118(10)$ & $14.2542(6)$ & $19.9917(5)$ \\
\hline$\alpha /^{\circ}$ & 90 & $107.851(4)$ & 90 \\
\hline$\beta /^{\circ}$ & $94.244(6)$ & $100.439(4)$ & $93.683(3)$ \\
\hline$\gamma /{ }^{\circ}$ & 90 & $100.556(4)$ & 90 \\
\hline$V / \AA^{3}$ & $1411.23(17)$ & $1050.66(8)$ & $2378.05(11)$ \\
\hline$Z$ & 2 & 1 & 2 \\
\hline$D_{x} / \mathrm{g} \mathrm{cm}^{-3}$ & 2.082 & 1.854 & 1.689 \\
\hline$\mu / \mathrm{mm}^{-1}$ & 10.667 & 7.190 & 6.355 \\
\hline$\theta$ range $/^{\circ}$ & $2.9-27.5$ & $3.0-27.5$ & $2.8-27.5$ \\
\hline Reflections measured & 15284 & 12872 & 26714 \\
\hline Independent reflections; $R_{\text {int }}$ & $3218 ; 0.030$ & $4751 ; 0.054$ & $5408 ; 0.032$ \\
\hline Reflections with $I>2 \sigma(I)$ & 2955 & 4433 & 4894 \\
\hline Number of parameters & 149 & 254 & 254 \\
\hline$R(F)[I>2 \sigma(I)$ reflections $]$ & 0.025 & 0.024 & 0.021 \\
\hline$a, b$ in weight scheme & $0.031,3.103$ & $0.008,0$ & $0.010,1.698$ \\
\hline $\mathrm{w} R\left(F^{2}\right)$ (all data) & 0.064 & 0.044 & 0.041 \\
\hline $\operatorname{GOF}\left(F^{2}\right)$ & 1.08 & 0.97 & 1.05 \\
\hline 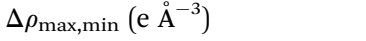 & $1.71,-1.46$ & $1.12,-1.31$ & $0.59,-0.61$ \\
\hline
\end{tabular}

aseptically placed on Mueller-Hinton agar surfaces and $5 \mu \mathrm{l}$ of the dissolved compounds were immediately added to discs. DMSO was used as a negative control whereas standard antibiotic paper disc was used as the positive control. All plates were incubated at $37^{\circ} \mathrm{C}$ for $24 \mathrm{~h}$. The anti-bacterial activity was evaluated by measuring the diameter of the inhibition zone against the test bacterial strains. Each trial was performed in triplicate.

Minimum inhibitory concentration (MIC) and minimum bactericidal concentration (MBC) determination. The MIC was determined by the broth micro-dilution method according to the NCCLS guidelines. An inoculum suspension with a density $10^{5} \mathrm{CFU} \mathrm{ml} \mathrm{ml}^{-1}$ of exponentially growing bacterial cells was added into each well. The test compounds were serially two-fold diluted in DMSO and then added to each well of a 96-well microplate. The 96-well microplates were incubated at $37^{\circ} \mathrm{C}$ for 24 h. All tests were performed in triplicate. Four controls comprising medium with standard anti-biotic (positive control), medium with DMSO (solvent control), medium with inoculum bacterial cells (negative control) and medium with broth only (negative growth control) were included in each test. The bacterial growth was detected by adding $50 \mu \mathrm{l}$ of a $0.2 \mathrm{mg} \mathrm{ml} \mathrm{m}^{-1}$ $p$-iodonitrotetrazolium violet (INT) indicator solution into each of the microplate wells and incubated at $37^{\circ} \mathrm{C}$ for $30 \mathrm{~min}$. under aerobic agitation. The INT changed from clear to red in the presence of bacterial activity. Where bacterial growth was inhibited, the suspension in the well remained clear after incubation with INT. The lowest concentration of the tested compound which completely inhibited bacterial growth was taken as the MIC. After MIC determination of each tested compound, an aliquot of $100 \mu \mathrm{l}$ from each well which showed no visible growth was spread onto MHA at $37{ }^{\circ} \mathrm{C}$ for $24 \mathrm{~h}$. The MBC is defined as the lowest concentration of the tested compound at which bacteria are killed.

\section{Results and discussion}

\section{Syntheses and spectroscopy}

The reaction of $p$-phenylene di-isothiocyanate with $\mathrm{MeOH}$ in the presence of base yielded bipodal $\mathrm{LH}_{2}$ in high yield. The ${ }^{1} \mathrm{H}$ and, especially, ${ }^{13} \mathrm{C}$ NMR of $\mathrm{LH}_{2}$ showed unexpected features in that chemically equivalent sites gave multiple resonances. Accordingly, a variable temperature ${ }^{1} \mathrm{H}$ NMR study in DMSO- $d_{6}$ solution (to attain a wider temperature range) was conducted with the results summarised in Table 2. Two resonances were observed for the ring protons when equivalence might have been expected. The splitting is ascribed to the formation of intramolecular methyl-C-H $\cdots \pi($ aryl $)$ interactions rendering the protons

Table 2 Variable temperature ${ }^{1} \mathrm{H}$ NMR data $\left(\delta\right.$, ppm; $W_{1 / 2}$, band width at half-height) for $\mathrm{LH}_{2}$ recorded in DMSO- $d_{6}$ solution

\begin{tabular}{lllll}
\hline Temp. $\left({ }^{\circ} \mathrm{C}\right)$ & $\mathrm{NH}$ & aryl-H & Ome & $W_{1 / 2}(\mathrm{~Hz})$ \\
\hline 28 & 11.08 & $7.59,7.29$ & 3.98 & 29.32 \\
38 & 11.04 & $7.57,7.31$ & 3.98 & 12.40 \\
48 & 10.99 & 7.41 & 3.98 & 6.52 \\
58 & 10.95 & 7.44 & 3.99 & 4.95 \\
68 & 10.90 & 7.44 & $3.99(\mathrm{sh}, 3.98)$ & 3.17 \\
78 & 10.86 & 7.44 & $4.00(\mathrm{sh}, 3.98)$ & 2.29
\end{tabular}


inequivalent. Upon heating the solution, the two signals coalesced into a single resonance, most likely due to rapid exchange, ESI Fig. S2a. $\dagger$ While no splitting was observed for the resonance due to the methyl protons, marked sharpening of the signal was evident as manifested in the $\mathrm{W}_{1 / 2}$ values of $29.32 \mathrm{~Hz}$ at $28{ }^{\circ} \mathrm{C} c f$. $2.29 \mathrm{~Hz}$ at $78{ }^{\circ} \mathrm{C}$, indicative of a rapid exchange process, ESI Fig. S2b. $\uparrow$ This was accompanied by a small downfield shift. The $\mathrm{N}$-bound proton shifted upfield with increasing temperature consistent with reduced hydrogen bonding with the solvent. Evidence that the reduction in hydrogen bonding was a two-step process was found in the appearance of a shoulder for the methyl-proton at $68{ }^{\circ} \mathrm{C}$ consistent with the appearance of a minor, new species. The two environments arise at high temperature as one $\mathrm{N}$-bound proton is involved in hydrogen bonding with the solvent and the other is not, $c f$. both participating in hydrogen bonding at low temperature.

Upon deprotonation and coordination of $\mathrm{LH}_{2}$, the ${ }^{1} \mathrm{H}$ NMR resonance at $8.32\left(\mathrm{CDCl}_{3}\right)$ ascribed to $\mathrm{N}-\mathrm{H}$ no longer persists in the spectra of 1-3. By contrast to the spectrum recorded for $\mathrm{LH}_{2}$, all chemically equivalent nuclei resonated at the same field strength. Also noteworthy are the significant upfield shifts in the resonances due to aryl- $\mathrm{H}$ of the central ring, i.e. to 6.72, 6.41 and 6.84 for 1-3, respectively $c f$. 7.56 and 7.22 observed for $\mathrm{LH}_{2}$. This observation is correlated with the presence of intramolecular $\mathrm{Au} \cdots \pi$ (aryl) interactions as delineated by X-ray crystallography (see below). The key finding of the ${ }^{13} \mathrm{C}\left\{{ }^{1} \mathrm{H}\right\}$ NMR spectra was that the four phenyl hydrogen-bearing nuclei, ortho and meta, are equivalent and appear as a single resonance in $\mathrm{CDCl}_{3}$ solution. Similarly, the quaternary ipso carbons are also equivalent. In the ${ }^{31} \mathrm{P}$ NMR, a single resonance was observed for 1-3 at 35.6, 38.1 and 56.5, respectively, which are deshielded with respect to the uncoordinated $\mathrm{Et}_{3} \mathrm{P}(-20.0), \mathrm{Ph}_{3} \mathrm{P}(-5.2)$ and $\mathrm{Cy}_{3} \mathrm{P}(9.2)$ molecules measured under the same conditions. The relaxation attributes of $\mathbf{1}$, being representative of the series, were also investigated.

In the ${ }^{13} \mathrm{C}\left\{{ }^{1} \mathrm{H}\right\}$ NMR spectrum of 1 , the ortho and meta carbons of the central ring resonated at $\delta=122.84 \mathrm{ppm}$. At $20{ }^{\circ} \mathrm{C}$ in $\mathrm{CDCl}_{3}$ solution, the observed ${ }^{13} \mathrm{C}$ spin-lattice relaxation time $\left(T_{1}\right)$ for this resonance was $0.69 \mathrm{~s}$, and the $\mathrm{NOE}=2.88$; the NOE enhancement factor, $\eta$, was 1.88 . As this $\eta$ value is very near the maximum value of 1.988 for a ${ }^{13} \mathrm{C}$ nucleus, the dominant relaxation mechanism is the dipole-dipole relaxation mechanism $\left(T_{1}^{\mathrm{dd}}\right)$, for which the rate of this dipolar relaxation (1/ $T_{1}^{\mathrm{dd}}$ ), is proportional to the correlation time. ${ }^{12,25}$ The observed $T_{1}$ is very low for phenyl nuclei in solution and is consistent with very low mobility of the phenyl group in the molecule. Hence, the observed ${ }^{13} \mathrm{C}$ relaxation data are consistent with severe hindrance in the internal rotation of the phenyl group.

The IR spectra of compounds 1-3 confirmed the absence of broad absorption at $3219 \mathrm{~cm}^{-1}$, due to $v(\mathrm{~N}-\mathrm{H})$ in $\mathrm{LH}_{2}$. Further, the red shifts of the $v(\mathrm{C}-\mathrm{N})$ absorption to $\sim 1400 \mathrm{~cm}^{-1}$, and blue shifts of $v(\mathrm{C}=\mathrm{S})$ to $\sim 1100 \mathrm{~cm}^{-1}$ in 1-3 when compared to $\mathrm{LH}_{2}$ provide further evidence for complexation.

\section{Crystallography}

The crystal structures of 1-3 were established by X-ray crystallography: the molecular structures are shown in Fig. 1 and selected geometric parameters are collated in Table 3. The molecule in 1, Fig. 1a, is located about a centre of inversion and features a linear gold atom geometry defined by the phosphane$\mathrm{P}$ and thiolate-S atoms. As usual for this type of structure, ${ }^{6}$ the $\mathrm{Au}-\mathrm{S}$ bond length is longer than that of $\mathrm{Au}-\mathrm{P}$. As the crystal

(a)
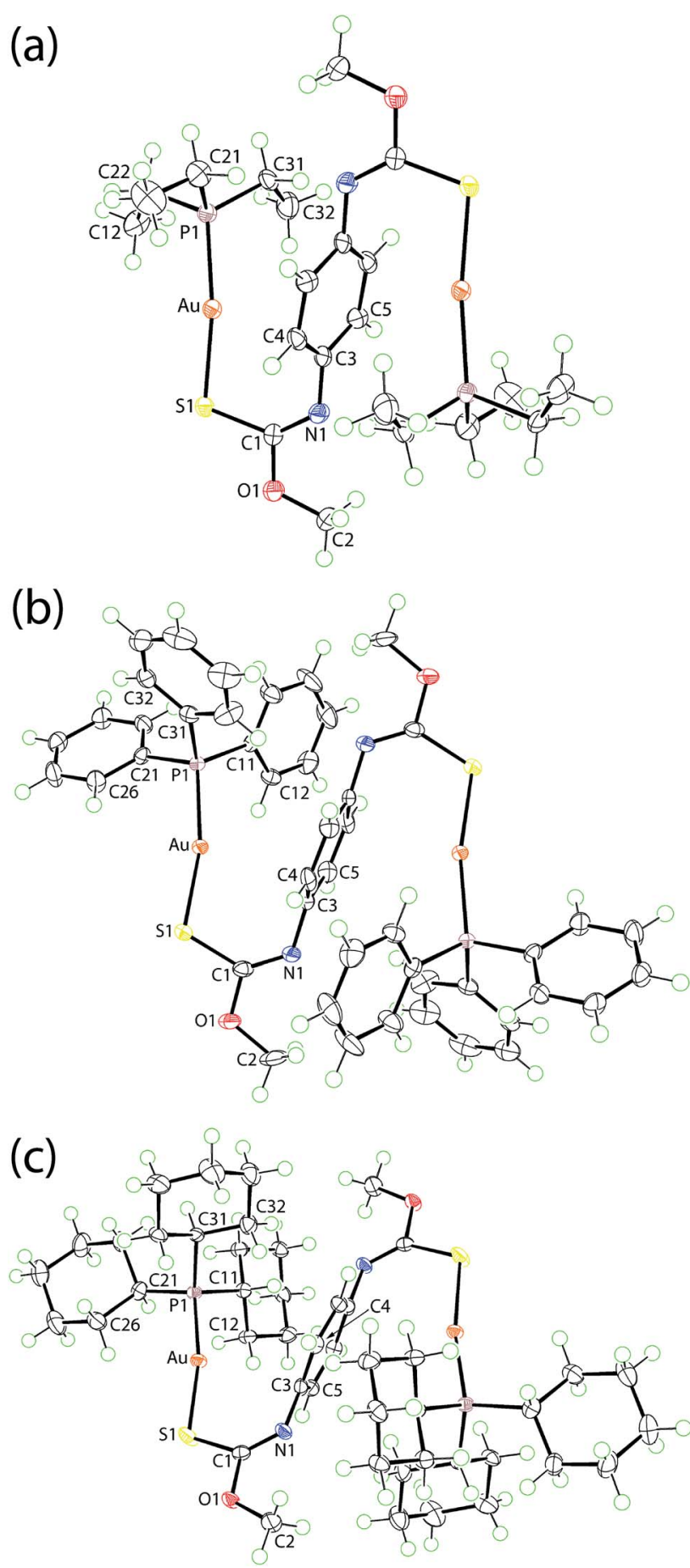

Fig. 1 Perspective views of the molecules of (a) 1, (b) 2 and (c) 3. Displacement ellipsoids are drawn at the $70 \%$ probability level and hydrogen atoms are shown as small spheres of arbitrary radii. The unlabelled atoms in (a) are related by the symmetry operation $1-x$, $2-y,-z$, and in (b) and (c) by $1-x, 1-y,-z$. 
Table 3 Selected bond lengths $(\AA)$ and angles $\left(^{\circ}\right)$ for $1-3$

\begin{tabular}{llll}
\hline & $\mathbf{1}$ & $\mathbf{2}$ & $\mathbf{3}$ \\
\hline $\mathrm{Au}-\mathrm{S} 1$ & $2.3152(10)$ & $2.3058(9)$ & $2.3019(6)$ \\
$\mathrm{Au}-\mathrm{P} 1$ & $2.2663(10)$ & $2.2593(9)$ & $2.2695(6)$ \\
$\mathrm{C} 1-\mathrm{S} 1$ & $1.762(4)$ & $1.761(3)$ & $1.756(3)$ \\
$\mathrm{C} 1-\mathrm{O} 1$ & $1.372(5)$ & $1.356(4)$ & $1.362(3)$ \\
$\mathrm{C} 1-\mathrm{N} 1$ & $1.258(5)$ & $1.268(4)$ & $1.263(3)$ \\
$\mathrm{S} 1-\mathrm{Au}-\mathrm{P} 1$ & $172.13(4)$ & $167.79(3)$ & $168.63(2)$ \\
$\mathrm{Au}-\mathrm{S} 1-\mathrm{C} 1$ & $107.07(14)$ & $107.37(12)$ & $111.77(9)$ \\
$\mathrm{C} 1-\mathrm{N} 1-\mathrm{C} 3$ & $123.5(4)$ & $122.3(3)$ & $124.8(2)$ \\
$\mathrm{S} 1-\mathrm{C} 1-\mathrm{O} 1$ & $108.5(3)$ & $108.1(2)$ & $106.82(17)$ \\
$\mathrm{S} 1-\mathrm{C} 1-\mathrm{N} 1$ & $132.8(3)$ & $131.3(3)$ & $134.3(2)$ \\
$\mathrm{O} 1-\mathrm{C} 1-\mathrm{N} 1$ & $118.7(4)$ & $120.6(3)$ & $118.8(2)$ \\
$\mathrm{Au} \cdots \mathrm{Cg}(\operatorname{aryl})^{a}$ & 3.26 & 3.32 & 3.55 \\
$\alpha^{a}$ & 22.7 & 21.6 & 30.7
\end{tabular}

${ }^{a} \alpha$ is the angle between the normal to the plane through the central ring and the vector passing through the centroid $(\mathrm{Cg})$ of the aryl ring to the $\mathrm{Au}$ atom.

structure of the precursor thiocarbamide, $\mathrm{LH}_{2}$, is not available, the comparison between the geometric parameters defining the thiolate ligand in 1 will be made with $\mathrm{PhN}(\mathrm{H}) \mathrm{C}(=\mathrm{S}) \mathrm{OMe} .^{26}$ The most notable observations is the elongation of the $\mathrm{C} 1-\mathrm{S} 1$ and contraction of the $\mathrm{C} 1-\mathrm{N} 1$ bond lengths in 1, Table 1, compared with 1.6708(11) and 1.3288(15) $\AA$, respectively in the uncoordinated molecule. ${ }^{26}$ These changes are consistent with $\mathrm{L}^{2-}$ coordinating each gold atom as a thiolate ligand. The rearrangement of electron density in the anion also results in significant differences in bond angles whereby the S1-C1-O1 angle has contracted by about $16^{\circ}$, and the $\mathrm{S} 1-\mathrm{C} 1-\mathrm{N} 1$ and O1-C1-N1 angles have expanded by about 10 and $6^{\circ}$, respectively, observations readily correlated with the increased electron density in the C1-N1 bond. The molecular structures of 2 and $\mathbf{3}$ have essentially the same features as described for $\mathbf{1}$, as highlighted in the overlay diagram shown in Fig. 2 that shows only small conformational variations. According to a search of the Cambridge Structural Database (CSD), ${ }^{27}$ there are no

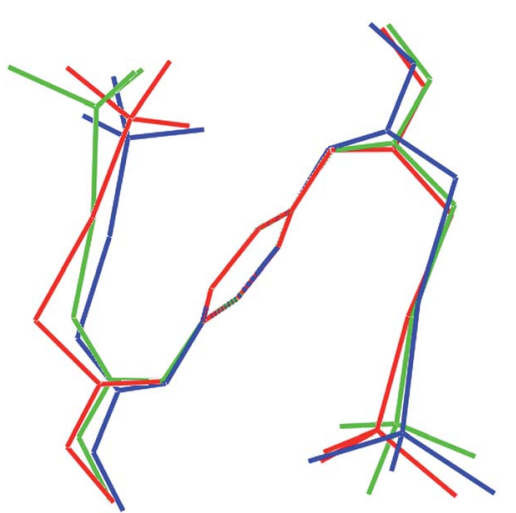

Fig. 2 Overlay diagram of 1 (red image), 2 (green) and 3 (blue). No hydrogen atoms are shown and only the $\alpha$-carbon atoms of the phosphane ligands are included. The molecules have been overlapped so that the central rings are coincident. precedents for binuclear structures based on bipodal thiocarbamates or analogues of higher denticity.

The crystal packing of $\mathbf{1}$ is devoid of directional intermolecular interactions and may be described as comprising columns of molecules parallel to the $a$-axis, ESI Fig. S3a. $\dagger$ Weak $\mathrm{C}-\mathrm{H} \cdots \pi($ aryl $)$ interactions are noted in the crystal packing of 2, and methylene$\mathrm{C}-\mathrm{H} \cdots \mathrm{O}$ contacts are seen in 3 . Despite these and the disparity in space groups, Table 1, the packing for each of 2 and 3 is as described for 1, i.e. comprising columns of molecules aligned along the $a$-axis, ESI Fig. S3b and c. $\dagger$

The linear coordination geometries for gold deviate by up to $12^{\circ}$ from the ideal, deviations that are ascribed to the presence of intramolecular $\mathrm{Au} \cdots \pi(\operatorname{aryl})$ interactions, Table 3. Such deviations are usually observed in related mononuclear structures of $[\mathrm{MeOC}(\mathrm{S})=\mathrm{NR}]^{-}$but more often than not due to intramolecular $\mathrm{Au} \cdots \mathrm{O}$ interactions. Indeed, of the 31 structures available in the $\mathrm{CSD}^{27}$ with the general formula, $\mathrm{R}_{3} \mathrm{PAu}$ $\left[\mathrm{SC}(\mathrm{OMe})=\mathrm{NR}^{\prime}\right]$, and diphosphane analogues, ${ }^{6 \boldsymbol{a}, 28} 27$ feature $\mathrm{Au} \cdots \mathrm{O}$ interactions in the range $2.862(3) \AA$ for $\mathrm{R}=\mathrm{Ph} \&$ $\mathrm{R}^{\prime}=p$-tol, ${ }^{6 c}$ to $3.172(8) \AA$ for $\mathrm{R}=\mathrm{Cy} \& \mathrm{R}^{\prime}=p-\mathrm{NO}_{2} \mathrm{Ph} .{ }^{6 a}$ The remaining structures, each with isomeric tol ${ }_{3} \mathrm{P}$ ligands, were reported to form intramolecular $\mathrm{Au} \cdots \pi$ (aryl) interactions in the absence of steric hindrance and by judicious combinations of $\mathrm{R}$ and $\mathrm{R}^{\prime}$ groups. ${ }^{6 c}$ Given that in no circumstances were intramolecular $\mathrm{Au} \cdots \pi$ (aryl) interactions formed for $\mathrm{R}_{3} \mathrm{P}$ ligands with $\mathrm{R}=\mathrm{Et}$, $\mathrm{Ph}$ or $\mathrm{Cy}$, the observation of these interactions in 1-3 was unexpected. The fickle nature of the formation of $\mathrm{Au} \cdots \pi($ aryl $)$ interactions is probably best illustrated in the polymorphs of $\operatorname{dppm}(\mathrm{AuCl})_{2}$ where in one form, an intramolecular $\mathrm{Au} \cdots \mathrm{Au}$ interaction is formed within an A-frame arrangement, ${ }^{29 a}$ whereas in the other polymorph, an intramolecular $\mathrm{Au} \cdots \pi(\operatorname{aryl})$ interaction was observed instead. ${ }^{29 \boldsymbol{b}}$ In order to probe further the nature of the $\mathrm{Au} \cdots \pi$ (aryl) interactions formed in 1-3, 1 was subjected to a computational study.

\section{Optimised molecular structures}

Phosphanegold(I) thiolates sometimes present unexpected structures. ${ }^{30}$ For example, in structures of the type $\mathrm{R}_{3} \mathrm{PAu}$ $\left[\mathrm{SC}(=\mathrm{S}) \mathrm{OR}^{\prime}\right], \mathrm{R}, \mathrm{R}^{\prime}=$ alkyl/aryl, intramolecular $\mathrm{Au} \cdots \mathrm{O}$ interactions are usually formed giving rise to compact structures, rather than the intramolecular $\mathrm{Au} \cdots \mathrm{S}$ contacts expected from hard acid/soft base considerations. The latter interactions lead to open, rod-like molecular structures. ${ }^{30 a-c}$ In a similar vein, in a related species, i.e. $\mathrm{Cy}_{3} \mathrm{PAu}\left[\mathrm{SC}_{6} \mathrm{H}_{4}-2-\mathrm{CO}_{2} \mathrm{H}\right]$, in one polymorph the anticipated eight-membered $\{\ldots \mathrm{HOCO}\}_{2}$ synthon is formed, linking molecules in the crystal structure to form rod-type conformations. However, in each of the three other polymorphs, intramolecular $\mathrm{O}-\mathrm{H} \cdots \mathrm{S}$ (thiolate) hydrogen bonds are formed instead, leading to spherical molecules. ${ }^{30 d, \boldsymbol{e}}$ The unexpected structures were rationalised in terms of global crystal packing considerations, ${ }^{31}$ in that the packing of spherical aggregates is more efficient that the packing of "rods". ${ }^{30}$

Geometry optimisation calculations were performed on 1 with the energy minimised structure having a conformation very similar to the experimentally observed structure. As highlighted in Fig. 3, there has been a flattening in the $\mathrm{N}=\mathrm{C}-\mathrm{S}-\mathrm{Au}$ part of the 
geometry optimised molecule as manifested in the N1-C1-S1-Au dihedral angle of $-0.9^{\circ}, c f .14 .8(5)^{\circ}$ in the experimental structure. Conformational differences are also noted in the phosphanebound ethyl groups. Further, the calculations show that the conformation presenting two intramolecular $\mathrm{Au} \cdots \tau$ (aryl) contacts, as is experimentally observed in the crystal structure of 1 , is more stable by $12.2 \mathrm{kcal} \mathrm{mol}^{-1}$ with respect to the conformation featuring one $\mathrm{Au} \cdots \pi($ aryl $)$ contact and one $\mathrm{Au} \cdots \mathrm{O}$ contact, and by $23.6 \mathrm{kcal} \mathrm{mol}^{-1}$ than the rod-like conformer with two Au $\cdots$ $\mathrm{O}$ interactions, Fig. 4. These results shown the Au $\cdots \pi$ (aryl) interaction is much stronger than $\mathrm{Au} \cdots \mathrm{O}$, and roughly additive.

The Bader delocalization indices (DI's) ${ }^{32}$ were calculated at the LC- $\omega$ PBE-XDM level between gold and the rest of the atoms in the three studied conformations. Intermolecular DI's are an excellent tool to evaluate the degree of electron delocalization (charge transfer) between interacting fragments. ${ }^{33}$ For the conformations featuring $\mathrm{Au} \cdots \pi(\operatorname{aryl})$ interactions, there is a significant amount of electron sharing between the gold atoms and the central ring, indicating the existence of orbital interactions between the gold atom and the $\pi$-system, and justifying the high stability of this contact, Fig. 4 . The DI between the two gold atoms and the aryl ring is 0.56 in the compact conformer and 0.29 in the mixed $\mathrm{Au} \cdots \pi(\operatorname{aryl}) / \mathrm{Au} \cdots \mathrm{O}$ conformer. The degree of electron delocalization between $\mathrm{Au}$ and the thiocarbamate- $\mathrm{O}$ atom in the $\mathrm{Au} \cdots \mathrm{O}$ contact is relatively small in comparison (0.10), although larger than the DI with the atoms adjacent to the oxygen, which indicates an interaction weaker than $\mathrm{Au} \cdots \pi(\operatorname{aryl})$, in agreement with the energies. In addition, the $\mathrm{S}-\mathrm{Au}-\mathrm{P}$ angle is linear for the $\mathrm{Au} \cdots \mathrm{O}$ contact but bends slightly $\left(170^{\circ}\right)$ when a $\mathrm{Au} \cdots \pi($ aryl $)$ contact is present, indicating a steric clash between the P-bound ethyl groups and the central ring. Despite this steric clash, the large stabilization caused by electron delocalization across the intramolecular $\mathrm{Au} \cdots \pi$ (aryl) contact is clearly responsible for the conformation adopted in the crystal structure.

\section{Thermogravimetric analysis}

Traces for the thermogravimetric analysis for 1-3 are given in ESI Fig. S4. $\uparrow$ The decomposition pathways are quite similar for

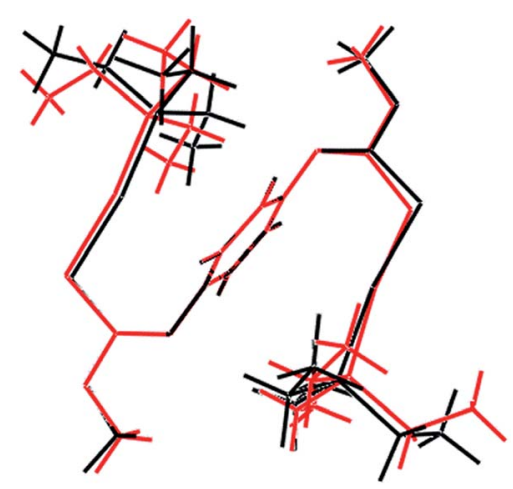

Fig. 3 Overlay diagram of the experimental molecular structure of 1 (red image) and the energy minimised structure (black). The molecules have been overlapped so that the central rings are coincident.
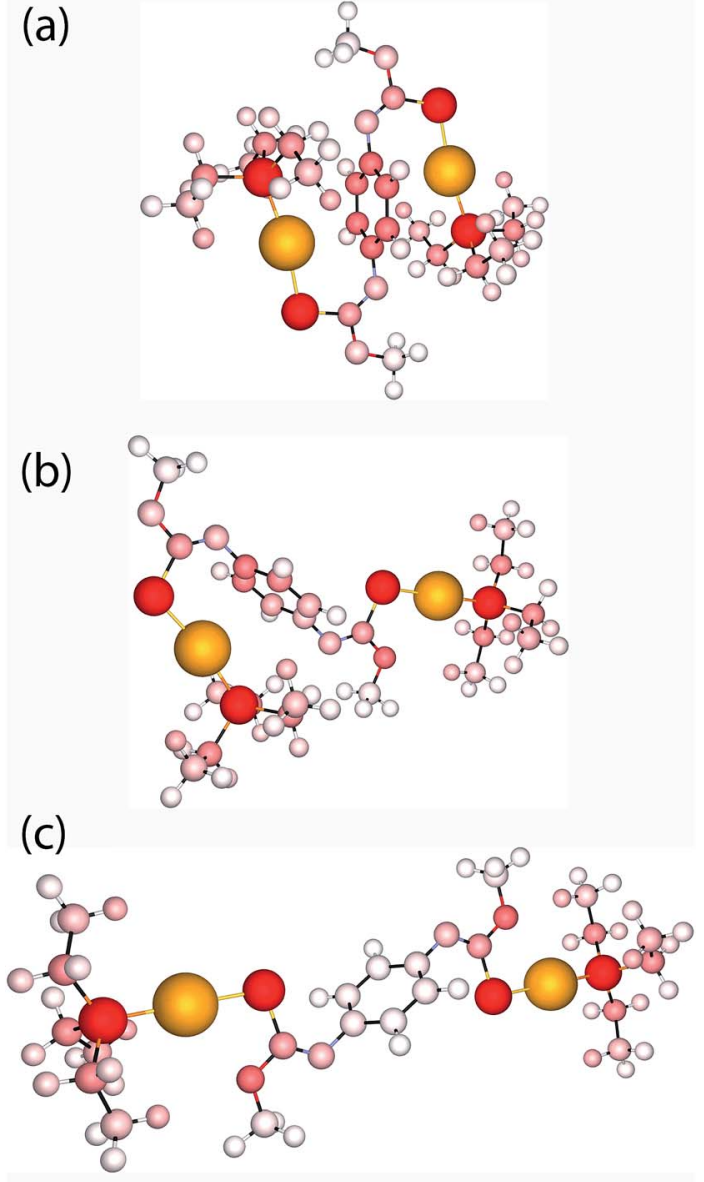

Fig. 4 Calculated structures for 1: (a) the compact, spherical,

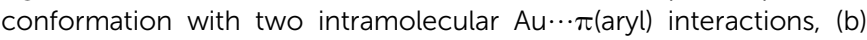
intermediate structure with one $\mathrm{Au} \cdots \pi(\operatorname{aryl})$ and one $\mathrm{Au} \cdots \mathrm{O}$ contact,

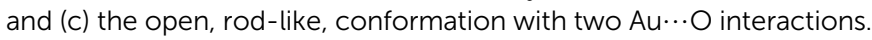
Bader's delocalization indices between gold (in orange) and all other individual atoms are given as a colour scale ranging from zero (white) to 0.30 (red).

1-3 and the following sequence is proposed. For 1, three discernible steps were resolved: step 1 - onset temperature $181.9{ }^{\circ} \mathrm{C}$ to end $226.9{ }^{\circ} \mathrm{C}$ resulted in a weight loss of $73.3 \%$ cf. $70.7 \%$ corresponding to the loss of $2 \mathrm{Et}_{3} \mathrm{P}$. The second step (226.9-441.8 ${ }^{\circ} \mathrm{C}$ ) saw a weight loss of $18.0 \% c f .21 .5 \%$, correlated with loss of (2L-2S) leaving $2 \mathrm{AuS}$ (obs., calcd weight remaining $52.7 \%$ cf. 51.8\%). The final step $\left(441.8-806.1^{\circ} \mathrm{C}\right)$ correlated with a weight loss of $7.2 \% c f$. $7.3 \%$ expected for the loss of $2 \mathrm{~S}$ with $2 \mathrm{Au}$ remaining (obs., calcd weight remaining $45.4 \%$ cf. $44.5 \%$ ). The difference between the decomposition pathway for $\mathbf{1}$ and those for $\mathbf{2}$ and $\mathbf{3}$ is that there is no clear distinction between the first two steps for 2 and 3. Thus, for 2, step 1, between 163.5 and $346.7^{\circ} \mathrm{C}$, is accompanied by a weight loss of $55.2 \% c f$. with $60.9 \%$ for the concomitant loss calculated for $2 \mathrm{Ph}_{3} \mathrm{P}$ and $(2 \mathrm{~L}-2 \mathrm{~S})$ (obs., calcd weight remaining for $2 \mathrm{AuS} 44.7 \% c f .39 .1 \%$ ), and step 2, between 346.7 and $815.2{ }^{\circ} \mathrm{C}$, having a weight loss of $9.8 \%$ cf. with the theoretical value of $5.5 \%$ expected for the loss of $2 \mathrm{~S}$ leaving $\mathrm{Au}$ (obs., calcd weight remaining for $2 \mathrm{Au} 35.0 \%$ 
cf. $33.6 \%$ ). The values for step 1 in the decomposition of 3 are onset-end temperatures 160.7 and $422.6{ }^{\circ} \mathrm{C}$ with $62.7 \%$ weight loss $c f$. with calculated $62.1 \%$ for the loss $2 \mathrm{Cy}_{3} \mathrm{P}$ and $(2 \mathrm{~L}-2 \mathrm{~S})$ (obs., calcd weight remaining for $2 \mathrm{AuS} 37.2 \% c f .37 .8 \%$ ), and for step 2, 422.6 to $815.2{ }^{\circ} \mathrm{C}$ with $3.6 \%$ weight loss $c f$. with calculated $5.3 \%$ for the loss $2 \mathrm{~S}$ (obs., calcd weight remaining for $2 \mathrm{Au}$ $33.6 \%$ cf. $32.6 \%)$.

\section{Evaluation of anti-bacterial activity}

A total of 24 strains of pathogen were screened in the present study, and the results of the disk diffusion assay are presented in the Table 4. Compounds 1-3 exhibited variable degrees of anti-bacterial activity against the clinically important pathogens tested; $\mathrm{LH}_{2}$ showed no inhibitory activity toward the tested bacteria. Of the series, 1 was the most active compound with complete inhibitory activity against all tested Grampositive and Gram-negative pathogens, except $P$. aeruginosa, which is only partially inhibited by $\mathbf{1}$. A partial zone of inhibition is defined as incomplete inhibition of bacterial growth and the formation of a film of bacteria on the surface agar. The Gram-positive bacteria were most susceptible toward 1, with greater inhibition zones, ranging from 18 to $30 \mathrm{~mm}$, compared with Gram-negative bacteria, with reduced inhibition zones, ranging from 7 to $23 \mathrm{~mm}$. Mild anti-bacterial activities against several Gram-positive bacteria were observed for 2 and 3, with clear zones of inhibition ranging from 7 to $10 \mathrm{~mm}$. Compound 2 was active against all the tested Gram-positive bacteria except $B$. cereus. By contrast, 3 exhibited the lowest activity of the series, being potent in only five of eight strains of Gram-positive bacteria, i.e. B. subtilis, E. faecium, L. monocytogenes, MRSA and S. saprophyticus. Clearly, in this preliminary anti-bacterial assay, the tested Gram-positive bacteria are more susceptible than Gram-negative bacteria. This finding is also supported by studies which reported that Gram-negative bacteria are less susceptible to anti-microbial agents $^{34}$ and is consistent with results obtained recently for mononcuclear phosphanegold(I) analogues. ${ }^{\mathbf{1 1}}$ The presence of the outer lipopolysaccharide layer in Gram-negative bacteria inhibits the access of most drugs to intracellular targets in bacteria and renders Gram-negative bacteria less susceptible to drugs than Gram-positive bacteria, which lack an outer membrane. ${ }^{35}$

Using the broth micro-dilution method, the anti-bacterial sensitivity of 1-3 was quantitatively assessed by determining the minimum inhibitory concentration (MIC), defined as the highest dilution at which no bacterial growth was detected, Table 5. A lower MIC value indicates a better anti-microbial agent as a smaller amount of trial compound is required to inhibit bacterial growth. Compound 1 exhibited excellent inhibitory activity toward all susceptible Gram-positive bacteria compared with 2 and 3 , and standard anti-biotics

Table 4 Anti-bacterial activity measured by zone of inhibition $(\mathrm{mm})$ of $1-3, \mathrm{LH}_{2}$ and standard anti-biotics ${ }^{c}$

\begin{tabular}{llllll}
\hline Microorganism & $\mathbf{1}$ & $\mathbf{2}$ & $\mathbf{3}$ & $\mathrm{LH}_{2}$ & Standard anti-biotics
\end{tabular}

Gram-positive bacteria

B. cereus ATCC 10876

B. subtilis ATCC6633

E. faecalis ATCC29212

E. faecium ATCC19434

L. monocytogenes ATCC19117

S. aureus (MRSA) ATCC 43300

S. aureus ATCC25923

S. saprophyticus ATCC15305

\section{Gram-negative bacteria}

A. baumannii ATCC19606

A. hydrophilla ATCC35654

C. freundii ATCC 8090

E. aerogenes ATCC13048

E. cloacae ATCC 35030

E. coli ATCC25922

K. pneumonia ATCC700603

P. aeruginosa ATCC 27853

P. mirabilis ATCC25933

P. vulgaris ATCC13315

S. typhimurium ATCC14028

S. paratyphiA ATCC 9150

S. flexneri ATCC12022

S. sonnei ATCC 9290

S. maltophilia ATCC13637

V. parahaemolyticus ATCC17802

\section{2}

27

20

18

20

23

30

30

13
8
8
7
8
10
8
$14(\mathrm{~T})$
8
14
9
9
12
10
9
23

-10
9
9
9
9
9
9

-

-

-

$\overline{-}$

$-$

${ }^{a}$ Tetracycline. $^{b}$ Chloramphenicol. ${ }^{c}$ The diamete
zone of inhibition; $(T)$, partial zone of inhibition. 
Table 5 MIC and MBC of 1-3, $\mathrm{LH}_{2}$ and standard anti-biotics against selected Gram-positive and Gram-negative bacteria ${ }^{c}$

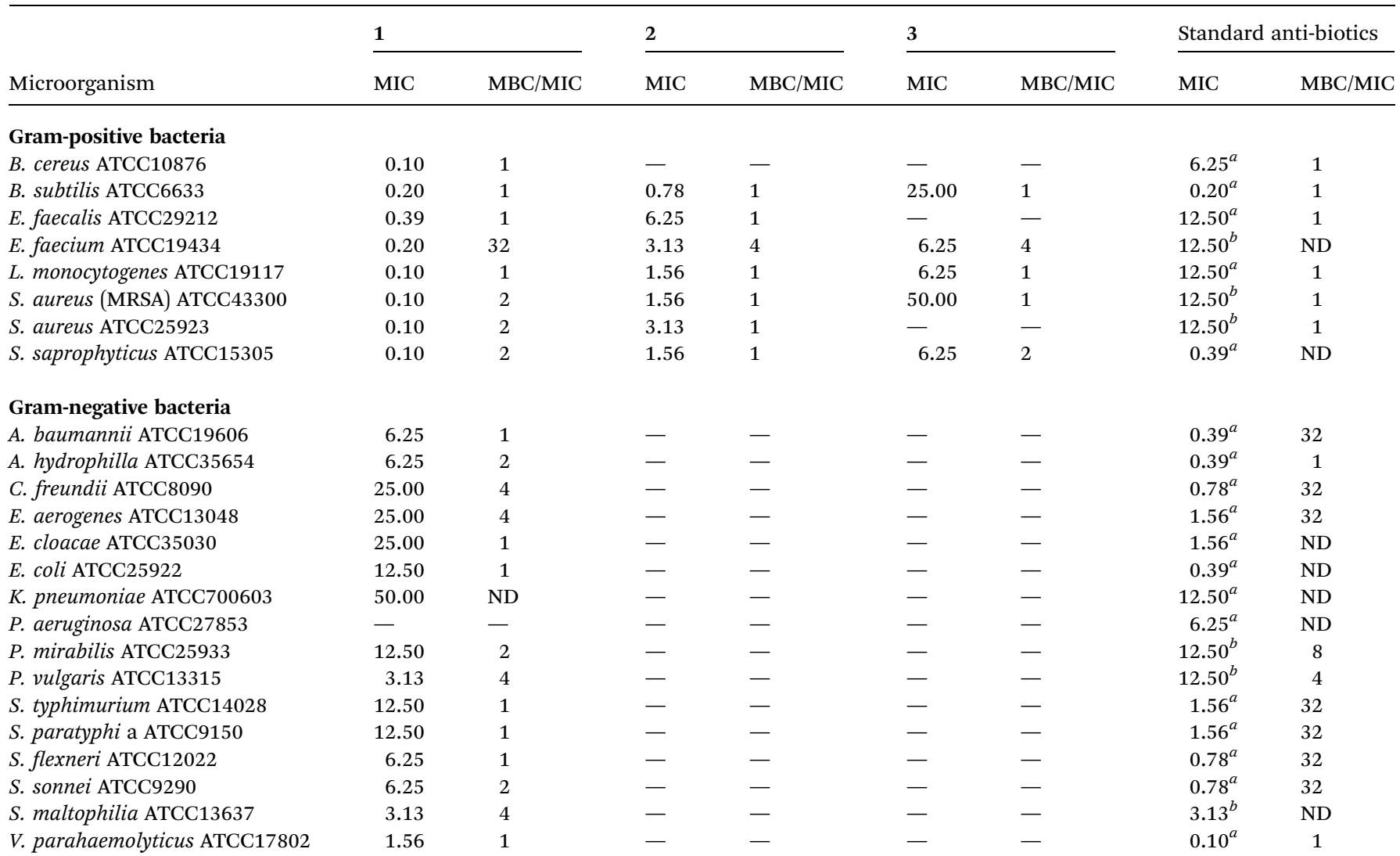

${ }^{a}$ Tetracycline. ${ }^{b}$ Chloramphenicol. ${ }^{c}$ MIC - minimum inhibitory concentration $\left(\mu \mathrm{g} \mathrm{ml}{ }^{-1}\right)$; MBC/MIC ratio for bacteriostatic or bactericidal activity; not applicable; ND - not determined as the bacterium had grown across all tested dilution ( $\mathrm{MBC}>100 \mu \mathrm{g} \mathrm{ml} l^{-1}$ ).

(tetracycline and chloramphenicol), with lowest MIC values in the range $0.10-0.39 \mu \mathrm{g} \mathrm{ml}{ }^{-1}$. The most susceptible Grampositive bacteria strains toward 1 were B. cereus, L. monocytogenes, MRSA, S. aureus and S. saprophyticus (MIC's $=0.10$ $\mu \mathrm{g} \mathrm{ml}^{-1}$ ) follow by B. subtilis and E. faecium (MIC's $=0.20 \mu \mathrm{g}$ $\mathrm{ml}^{-1}$ ) and E. faecalis (MIC $=0.39 \mu \mathrm{g} \mathrm{ml}^{-1}$ ). However, tetracycline and chloramphenicol showed equal or, normally, greater anti-bacterial activity toward Gram-negative bacteria compared to 1 , with lower MIC values in the range $0.10-12.5$ $\mu \mathrm{g} \mathrm{ml} \mathrm{m}^{-1}$. Compound 2 exhibited more promising MIC values (0.78-6.25 $\left.\mu \mathrm{g} \mathrm{ml} \mathrm{ml}^{-1}\right)$ than $3\left(6.25-50.00 \mu \mathrm{g} \mathrm{ml} \mathrm{m}^{-1}\right)$ toward susceptible Gram-positive bacteria. In addition, 2 displayed greater activity compared with tetracycline and chloramphenicol against E. faecalis, E. faecium, L. monocytogenes, MRSA and $S$. aureus, with lower MIC values in the range 1.56$6.25 \mu \mathrm{g} \mathrm{ml} \mathrm{m}^{-1}$.

The zone of inhibition and MIC tests may reflect temporary inhibition of bacterial growth (bacteriostatic) or bacterial killing (bactericidal) by a test compound. The bactericidal properties of 1-3 against susceptible strains were further analyzed by the minimum bactericidal concentration (MBC) assay and summarized as MBC/MIC ratios in Table 5. An anti-microbial agent is bactericidal if the $\mathrm{MBC}$ is not more than fourfold higher than the $\mathrm{MIC}$, i.e. $\mathrm{MBC} / \mathrm{MIC} \leq 4$. By contrast, the anti- microbial agent is bacteriostatic if the $\mathrm{MBC}$ is more than fourfold greater than the $\mathrm{MIC}$, i.e. $\mathrm{MBC} / \mathrm{MIC} \leq 4 .{ }^{36}$ Compounds 2 and 3 were shown to be bactericidal $(\mathrm{MBC} / \mathrm{MIC} \leq 4)$ toward the susceptible Gram-positive bacteria strains. For 1, bactericidal activity was observed against all susceptible Gram-positive and Gram-negative bacteria with the exception of $E$. faecium $(\mathrm{MBC} / \mathrm{MIC}=32)$ and $K$. pneumoniae $(\mathrm{MBC} / \mathrm{MIC}=\mathrm{ND})$. These results suggest that 1-3 are considered bactericidal agents but the activity of $\mathbf{1}$ is dependent on the specific bacterial strain.

The broad spectrum of activity exhibited by $\mathbf{1}(\mathrm{R}=\mathrm{Et})$ against Gram-positive and Gram-negative bacteria, and the specific activity against Gram-positive bacteria exhibited by 2 and 3 suggests a key role for the phosphane ligand. This is vindication of an earlier study against the same panel of 24 pathogens but where the thiolate was a dithiocarbamate ligand, i.e. $\mathrm{R}_{3} \mathrm{PAu}$ $\left[\mathrm{S}_{2} \mathrm{CN}(\mathrm{iPr}) \mathrm{CH}_{2} \mathrm{CH}_{2} \mathrm{OH}\right]$, for $\mathrm{R}=\mathrm{Et}, \mathrm{Ph}$ and $\mathrm{Cy} .{ }^{37}$ In this study a similar observation was made in that the $\mathrm{R}=$ Et derivative had broad range activity against both Gram-positive and Gramnegative bacteria, and the activity of the $\mathrm{R}=\mathrm{Ph}$ and $\mathrm{Cy}$ species was limited to Gram-positive bacteria. ${ }^{37}$ Perhaps once thought as being too expensive for development as antimicrobial agents, the emerging resistance to conventional therapies suggest that gold compounds may play a clinical role, especially against virulent strains of bacteria such as MRSA. 


\section{Conclusions}

Three new binuclear phospanegold(I) compounds of a bipodal ligand have been characterised. Crystallography shows the uniform adoption of a spherical aggregate featuring unexpected intramolecular $\mathrm{Au} \cdots \pi(\operatorname{aryl})$ interactions. Theory shows these interactions to be attractive, providing energies of stabilization to the molecular structure of 1 greater than $12 \mathrm{kcal} \mathrm{mol}^{-1}$ compared to putative $\mathrm{Au} \cdots \mathrm{O}$ interactions. Compounds 1-3 exhibited, predominantly, a bactericidal effect on Gram-positive (1-3) and Gram-negative (only 1) pathogens, with 1 perhaps having potential clinical benefits over standard anti-biotics in bacteriostatic therapy for immune-compromised patients, i.e. with cancer and neutropenia, by prompt elimination of the pathogen to therefore reduce the likelihood of the spread of infection.

\section{Acknowledgements}

Support from the Ministry of Higher Education, Malaysia, and the University of Malaya, for High Impact Research grant (UM.C/HIR-MOHE/SC/12) is gratefully acknowledged. AOR acknowledges support from the Spanish Malta/Consolider initiative (no. CSD2007-00045) and the Alberta Innovates Technology Futures (AITF) for funding.

\section{References}

1 e.g. S. S. Pathaneni and G. R. Desiraju, J. Chem. Soc., Dalton Trans., 1993, 319; M. J. Katz, K. Sakai and D. B. Leznoff, Chem. Soc. Rev., 2008, 37, 1884; H. Schmidbaur and A. Schier, Chem. Soc. Rev., 2008, 37, 1931; H. E. Abdou, A. A. Mohamed, J. P. Fackler, A. Burini, R. Galassi, J. M. Lopez-de-Luzuriaga and M. E. Olmos, Coord. Chem. Rev., 2009, 253, 1661; H. Schmidbaur and A. Schier, Chem. Soc. Rev., 2012, 41, 370; E. R. T. Tiekink, Coord. Chem. Rev., 2014, 275, 130.

2 P. Pyykkö and Y.-F. Zhao, Angew. Chem., Int. Ed. Engl., 1991, 30, 604; P. Pyykkö, Inorg. Chim. Acta, 2005, 358, 4113; H. Schmidbaur and A. Schier, Chem. Soc. Rev., 2008, 37, 1931; S. Sculforta and P. Braunstein, Chem. Soc. Rev., 2011, 40, 2741.

3 e.g. A. L. Balch, Struct. Bonding, 2007, 123, 1; V. W.-W. Yam and E. C.-C. Cheng, Top. Curr. Chem., 2007, 281, 269; E. R. T. Tiekink and J.-G. Kang, Coord. Chem. Rev., 2009, 253, 1627; X. He and V. W.-W. Yam, Coord. Chem. Rev., 2011, 255, 2111; E. E. Langdon-Jones and S. J. A. Pope, Chem. Commun., 2014, 50, 10343.

4 (a) I. Caracelli, J. Zukerman-Schpector and E. R. T. Tiekink, Gold Bull., 2013, 46, 81; (b) J. Zukerman-Schpector and E. R. T. Tiekink, CrystEngComm, 2009, 11, 1176; (c) E. R. T. Tiekink and J. Zukerman-Schpector, CrystEngComm, 2009, 11, 2701.

5 e.g. (a) B. K. Min and C. M. Friend, Chem. Rev., 2007, 107, 2709; (b) T. Takei, T. Akita, I. Nakamura, T. Fujitani, M. Okumura, K. Okazaki, J. H. Huang, T. Ishida and
M. Haruta, Adv. Catal., 2012, 55, 1; (c) M. Pan, J. L. Gong, G. B. Dong and C. B. Mullins, Acc. Chem. Res., 2014, 47, 750. 6 (a) S. Y. Ho, E. C.-C. Cheng, E. R. T. Tiekink and V. W.-W. Yam, Inorg. Chem., 2006, 45, 8165; (b) S. Y. Ho and E. R. T. Tiekink, CrystEngComm, 2007, 9, 368; (c) F. S. Kuan, S. Y. Ho, P. P. Tadbuppa and E. R. T. Tiekink, CrystEngComm, 2008, 10, 548.

7 (a) S. J. Berners-Price and A. Filipovska, Metallomics, 2011, 3, 863; (b) W. F. Kean and I. R. L. Kean, Inflammopharmacology, 2008, 16, 112; (c) E. R. T. Tiekink, Gold Bull., 2003, 36, 117; (d) J. F. Fries, D. Bloch, P. Spitz and D. M. Mitchell, Am. J. Med., 1985, 78, 56.

8 E. R. T. Tiekink, Critical Reviews in Oncology/Hematology, 2002, 42, 225; I. Ott, Coord. Chem. Rev., 2009, 253, 1670; C. Gabbiani, M. A. Cinellu, L. Maiore, L. Massai, F. Scaletti and L. Messori, Inorg. Chim. Acta, 2012, 393, 115; N. Cutillas, G. S. Yellol, C. de Haro, C. Vicente, V. Rodriguez and J. Ruiz, Coord. Chem. Rev., 2013, 257, 2784; C. Nardon, S. M. Schmitt, H. J. Yang, J. Zuo, D. Fregona and Q. P. Dou, PLoS One, 2014, 9, e84248; B. Bertrand and A. Casini, Dalton Trans., 2014, 4209.

9 C. I. Yeo, K. K. Ooi, A. Md Akim, K. P. Ang, Z. A. Fairuz, S. N. B. A. Halim, S. W. Ng, H.-L. Seng and E. R. T. Tiekink, J. Inorg. Biochem., 2013, 127, 24.

10 B. Đ. Glišić and M. I. Djuran, Dalton Trans., 2014, 5950.

11 C. I. Yeo, J.-H. Sim, C.-H. Khoo, Z.-J. Goh, K.-P. Ang, Y.-K. Cheah, Z. A. Fairuz, S. N. B. A. Halim, S. W. Ng, H.-L. Seng and E. R. T. Tiekink, Gold Bull., 2013, 46, 145.

12 R. K. Harris, Nuclear Magnetic Resonance Spectroscopy, Longman, Harlow, 1986.

13 X'Pert HighScore Plus, ed. B. V. Almelo, PANalytical, The Netherlands, 2009.

14 (a) V. J. Hall, G. Siasios and E. R. T. Tiekink, Aust. J. Chem., 1993, 46, 561; (b) S. Y. Ho, R. P. A. Bettens, D. Dakternieks, A. Duthie and E. R. T. Tiekink, CrystEngComm, 2005, 7, 682; (c) F. S. Kuan, F. Mohr, P. P. Tadbuppa and E. R. T. Tiekink, CrystEngComm, 2007, 9, 574.

15 (a) CrysAlisPro, Agilent Technologies, Santa Clara, CA, USA, 2014; (b) G. M. Sheldrick, Acta Crystallogr., Sect. A: Found. Crystallogr., 2008, 64, 112; (c) L. J. Farrugia, J. Appl. Crystallogr., 2012, 45, 849; (d) A. L. Spek, Acta Crystallogr., Sect. D: Biol. Crystallogr., 2009, 65, 148; (e) DIAMOND, Visual Crystal Structure Information System, Version 3.1, CRYSTAL IMPACT, Postfach 1251, D-53002 Bonn, Germany, 2006; (f) J. Gans and D. Shalloway, J. Mol. Graphics Modell., 2001, 19, 557.

16 M. J. Frisch, G. W. Trucks, H. B. Schlegel, G. E. Scuseria, M. A. Robb, J. R. Cheeseman, G. Scalmani, V. Barone, B. Mennucci, G. A. Petersson, H. Nakatsuji, M. Caricato, X. Li, H. P. Hratchian, A. F. Izmaylov, J. Bloino, G. Zheng, J. L. Sonnenberg, M. Hada, M. Ehara, K. Toyota, R. Fukuda, J. Hasegawa, M. Ishida, T. Nakajima, Y. Honda, O. Kitao, H. Nakai, T. Vreven, J. A. Montgomery Jr, J. E. Peralta, F. Ogliaro, M. Bearpark, J. J. Heyd, E. Brothers, K. N. Kudin, V. N. Staroverov, R. Kobayashi, J. Normand, K. Raghavachari, A. Rendell, J. C. Burant, S. S. Iyengar, J. Tomasi, M. Cossi, N. Rega, J. M. Millam, 
M. Klene, J. E. Knox, J. B. Cross, V. Bakken, C. Adamo, J. Jaramillo, R. Gomperts, R. E. Stratmann, O. Yazyev, A. J. Austin, R. Cammi, C. Pomelli, J. W. Ochterski, R. L. Martin, K. Morokuma, V. G. Zakrzewski, G. A. Voth, P. Salvador, J. J. Dannenberg, S. Dapprich, A. D. Daniels, Ö. Farkas, J. B. Foresman, J. V. Ortiz, J. Cioslowski and D. J. Fox, Gaussian 09, Revision A.1, Gaussian, Inc., Wallingford CT, 2009.

17 O. A. Vydrov and G. E. Scuseria, J. Chem. Phys., 2006, 125, 234109; O. A. Vydrov, J. Heyd, A. V. Krukau and G. E. Scuseria, J. Chem. Phys., 2006, 125, 074106.

18 A. D. Becke and E. R. Johnson, J. Chem. Phys., 2007, 127, 154108.

19 E. R. Johnson and A. D. Becke, J. Chem. Phys., 2006, 124, 174104.

20 A. Otero-de-la-Roza and E. R. Johnson, J. Chem. Phys., 2013, 138, 204109.

21 http:/gatsby.ucmerced.edu/.

22 A. Otero-de-la-Roza, J. D. Mallory and E. R. Johnson, J. Chem. Phys., 2014, 140, 18A504.

23 K. A. Peterson and C. Puzzarini, Theor. Chem. Acc., 2005, 114, 283.

24 E. R. Johnson, A. Otero-de-la-Roza, S. G. Dale and G. A. DiLabio, J. Chem. Phys., 2013, 139, 214109.

25 S. Ng, F. M. Salleh, Y. Xie and H. F. Schaefer III, J. Phys. Org. Chem., 2012, 25, 1374.

26 S. Y. Ho, C. S. Lai and E. R. T. Tiekink, Acta Crystallogr., Sect. E: Struct. Rep. Online, 2003, 59, 01155.

27 C. R. Groom and F. H. Allen, Angew. Chem., Int. Ed., 2014, 53, 662.

28 P. P. Tadbuppa and E. R. T. Tiekink, Acta Crystallogr., Sect. E: Struct. Rep. Online, 2007, 63, m1101; P. P. Tadbuppa and E. R. T. Tiekink, Acta Crystallogr., Sect. E: Struct. Rep. Online, 2009, 65, m1557; P. P. Tadbuppa and E. R. T. Tiekink, Acta Crystallogr., Sect. E: Struct. Rep. Online, 2009, 65, m1558; P. P. Tadbuppa and
E. R. T. Tiekink, Acta Crystallogr., Sect. E: Struct. Rep. Online, 2009, 65, m1646; P. P. Tadbuppa and E. R. T. Tiekink, Acta Crystallogr., Sect. E: Struct. Rep. Online, 2009, 65, m1700; P. P. Tadbuppa and E. R. T. Tiekink, Acta Crystallogr., Sect. E: Struct. Rep. Online, 2010, 66, m450; P. P. Tadbuppa and E. R. T. Tiekink, Acta Crystallogr., Sect. E: Struct. Rep. Online, 2010, 66, m664.

29 (a) H. Schmidbaur, A. Wohlleben, F. Wagner, O. Orama and G. Huttner, Chem. Ber., 1977, 110, 1748; (b) P. C. Healy, Acta Crystallogr., Sect. E: Struct. Rep. Online, 2003, 59, m1112.

30 (a) G. Siasios and E. R. T. Tiekink, Z. Kristallogr., 1993, 204, 95; (b) G. Siasios and E. R. T. Tiekink, Z. Kristallogr., 1993, 205, 261; (c) E. R. T. Tiekink and I. Haiduc, Prog. Inorg. Chem., 2005, 54, 127; (d) P. D. Cookson and E. R. T. Tiekink, J. Coord. Chem., 1992, 26, 313; (e) D. R. Smyth, B. R. Vincent and E. R. T. Tiekink, Cryst. Growth Des., 2001, 1, 113.

31 J. D. Dunitz and A. Gavezzotti, Acc. Chem. Res., 1999, 32, 677; J. D. Dunitz and A. Gavezzotti, Chem. Soc. Rev., 2009, 38, 2622; J. D. Dunitz and A. Gavezzotti, Cryst. Growth Des., 2012, 12, 5873.

32 R. F. W. Bader and M. E. Stephens, J. Am. Chem. Soc., 1975, 97, 7391; R. F. W. Bader, A. Streitwieser, A. Neuhaus, K. E. Laidig and P. Speers, J. Am. Chem. Soc., 1996, 118, 4959. 33 A. Otero de la Roza, E. R. Johnson and G. A. DiLabio, J. Chem. Theory Comput., 2014, 10, 5436.

34 K. S. O. Ferraz, N. F. Saliva, J. G. D. Silva, L. F. D. Miranda, C. F. D. Romeiro, E. M. Souza-Fagundes, I. C. Mendes and H. Beraldo, Eur. J. Med. Chem., 2012, 53, 98.

35 P. Burn, Trends Biochem. Sci., 1998, 13, 79.

36 M. E. Levison, Infect. Dis. Clin., 2004, 18, 451.

37 J.-H. Sim, N. S. Jamaludin, C.-H. Khoo, Y.-K. Cheah, S. N. B. A. Halim, H.-L. Seng and E. R. T. Tiekink, Gold Bull., 2014, 47, 225. 